\title{
Nuclear Receptors as Drug Targets: A Historical Perspective of Modern Drug Discovery
}

Eckhard Ottow and Hilmar Weinmann

\section{1}

\section{Introduction}

Nuclear receptors are a large superfamily of transcription factors involved in important physiological functions such as control of embryonic development, organ physiology, cell differentiation and homeostasis [1-3]. Apart from the normal physiology, nuclear receptors have been identified to play a role in many pathological processes, such as cancer, diabetes, rheumatoid arthritis, asthma or hormoneresistance syndromes $[4,5]$. Therefore, despite their already long history, these transcriptional regulators are still of great interest in modern biomedical research and drug discovery.

Nuclear receptors are soluble proteins that can bind to specific DNA-regulatory elements and act as cell-type- and promoter-specific regulators of transcription [6]. In contrast to other transcription factors, the activity of nuclear receptors can be modulated by binding to the corresponding ligands - small lipophilic molecules that easily penetrate biological membranes. A number of nuclear receptors identified in recent years do not have any known ligands. These so-called orphan receptors have attracted considerable interest since they could lead to the discovery of new endocrine regulatory systems [7].

\section{2}

\section{Short Historical Overview on Nuclear Receptors in Pharmacological Research and Drug Discovery}

The first drugs in the nuclear receptor family were discovered prior to detailed pharmacological knowledge of the target class. Many compounds with clinical relevance were initially discovered by identification of biologically active compounds from natural extracts. Later, scientists used these biologically active molecules as tool compounds to derive the actual drug targets. Modern nuclear receptor-based 
endocrinology was built in many cases on pioneering experiments with bioactive fractions from natural extracts that contained steroid or thyroid hormones [8].

\subsection{1}

\section{Glucocorticoid Receptor Research}

Glucocorticoid receptor (GR) drug discovery was initiated by adrenal gland extracts. These tissue extracts were used by clinicians to treat Addison's disease (glucocorticoid deficiency) [9]. From these early clinical studies it was shown that the adrenal extract was related to the maintenance of homeostatic function. It was discovered that, apart from bringing about remission from stress-related diseases, these extracts also suppressed symptoms in patients suffering from inflammatory conditions such as allergy, hay fever and asthma. At the same time cortisone was identified as an active steroidal compound by biochemical characterization of these adrenal gland extracts. In 1948 sufficient quantities of cortisone could be purified and its effects in inflammatory disease could be tested. Finally, total syntheses of cortisone were independently achieved by R. B. Woodward et al. [10] and an industrial research group at Merck in the early 1950s [11]. For the commercial production of cortisone a process was established by the Merck process research and development group. Given that chemical development at that time was done without the support of today's analytical tools like nuclear magnetic resonance, mass spectrometry and modern chromatographic methods the successful large-scale transformation of desoxycholic acid to cortisone acetate in more than 30 steps with 18 isolated intermediates was a tremendous achievement [12] (Scheme 1.1).<smiles>CC(C)[C@H]1CCC2C3CCC4C[C@@H](O)CC[C@]4(C)C3C[C@H](O)[C@]21C</smiles>

Desoxycholic acid<smiles>CC(=O)OCC(=O)[C@]1(O)CCC2C3CCC4=CC(=O)CC[C@]4(C)C3C(=O)C[C@]21C</smiles>

Cortisone acetate<smiles>C[C@]12C=CC(=O)C=C1CCC1C2C(O)C[C@]2(C)C1CC[C@@]2(O)C(=O)CO</smiles>

Prednisolone<smiles>C[C@H]1CC2C3CCC4=CC(=O)C=C[C@]4(C)[C@@]3(F)[C@@H](O)C[C@]2(C)[C@]1(O)C(=O)CO</smiles>

Dexamethasone<smiles>C[C@H]1CC2C3C[C@H](F)C4=CC(=O)C=C[C@]4(C)C3[C@@H](O)C[C@]2(C)[C@H]1C(=O)CO</smiles>

Fluocortolon

Scheme 1.1 
\begin{tabular}{l|l|l}
1.2 Short Historical Overview on Nuclear Receptors in Pharmacological Research and Drug Discovery & 3
\end{tabular}

With this early success the further evolution of the first-generation steroidal glucocorticoids was started, and the stage for later syntheses of potent synthetic steroids such as prednisolone, dexamethasone and fluocortolon was set [13].

\subsection{2}

\section{Estrogen Receptor Research}

The first generation of drugs that targeted other steroid receptors was found by a similar history from natural sources. Estrone was isolated in 1929 as the first natural estrogenic hormone independently by the chemists E. A. Doisy and A. Butenandt from the urine of pregnant women, and its chemical structure was elucidated 1932 by A. Butenandt [14]. In 1938, H. H. Inhoffen achieved for the first time the synthesis of estradiol from cholesterol (Scheme 1.2). The first synthesis of ethinyl-estradiol, which has an improved oral bioavailability, was published in 1938 by H. H. Inhoffen and W. Hohlweg [15]. This discovery would later become one of the cornerstones of modern female fertility control and, even today, ethinyl-estradiol is an important component of many oral contraceptives.

From the very beginning, estrogen research also played an important role for other indications. It was known since 1916 that ovariectomy could decrease the incidence of mammary cancer in high-incidence strains of mice [16]. Studies of the biological effects of extracts containing estrogenic activity triggered screens for compounds with antiestrogenic effects - initially for contraception in the 1960s, but later for estrogen-responsive breast cancers. Screens for antiestrogenic nonsteroidal compounds led to the discovery of ethamoxytriphetol, clomiphene and tamoxifen. Tamoxifen finally became the gold standard for the endocrine treatment of breast cancer and the first approved cancer chemopreventative agent.

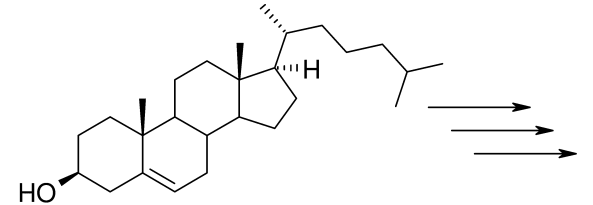

Cholesterol<smiles>C[C@]12CCC3c4ccc(O)cc4CCC3C1CC[C@@H]2O</smiles>

Estradiol<smiles>C=C[C@]1(O)CCC2C3CCc4cc(O)ccc4C3CCC21C</smiles>

Ethinylestradiol<smiles>CC/C(=C(\c1ccccc1)c1ccc(OCCN(C)C)cc1)c1ccccc1</smiles>

Tamoxifen

Scheme 1.2 


\subsection{3}

\section{Progesterone Receptor Research}

Progesterone was one of the first nuclear receptor hormones for which the functional role had been elucidated and used as a drug target. It plays an important role in female reproduction, controlling ovulation and maintaining pregnancy as well as in the growth and differentiation of endometrial and myometrial cells in the uterus.

The development of progesterone receptor (PR) ligands went through three important periods. In the beginning the development of steroid ligands that mimic the effect of natural progesterone was a major focus. Later on the development of steroids with improved properties and therapeutic applications was the central goal of synthetic work related to PR ligands. Nowadays, apart from further optimization of steroidal compounds, the development of nonsteroidal chemical entities with improved properties that might lead to still greater therapeutic applications is an important aspect of active drug discovery efforts [17].

As with other classic nuclear receptor hormones, identification and structure elucidation of progesterone started with the identification of a specific tissue that contained the biological activity. It was discovered at the beginning of the 20th century by surgical studies that removal of the corpus luteum led to the termination of pregnancy [18] and that extracts from the corpus luteum suppressed ovulation in rats [19]. It was demonstrated by Corner and Allen that gestational activity, including normal birth, can be restored in castrated rabbits by extracts from the corpus luteum [20]. This observation became a convenient assay to test progestational activity. Clauberg later developed a modified assay that eliminated the need for castration [21]. The isolation of purified crystalline corpus luteum hormone from sow ovaries was achieved by various groups in 1934 by applying these assays to identify the active fractions [22-25]. Ovaries from 10-15 sows were necessary to isolate enough purified hormone to induce the characteristic physiological changes in the uterus of one rabbit. Therefore, synthetic chemistry efforts were initiated to prepare the hormone in larger amounts. In these early synthetic studies readily available steroids from natural sources like cholesterol (from cow and pig fat), stigmasterol (from soy beans) and diosgenin (from Mexican yams) were used by various groups (Scheme 1.3) [26].

The observation that progesterone prevented ovulation was taken up by Haberlandt who was able to demonstrate that it could be used for fertility control [27]. In 1955, Gregory Pincus demonstrated that large doses of orally administered progesterone inhibited ovulation in women [28]. Despite its potential application as a contraceptive, the practical use of progesterone was limited by the fact that it is essentially inactive when administered orally. Therefore the discovery of a compound with contraceptive properties and better drug-like properties was the focus of synthetic efforts with progesterone as a lead structure. Inhoffen had discovered already in 1938 that $17 \alpha$-ethynyl-testosterone was a weakly active progestin when administered orally [29]. More than a decade later, in 1951 C. Djerassi and a team of scientists at Synthex succeeded in synthesizing 19-nor-17 $\alpha$-ethynyl-testosterone or 
<smiles>CC(C)CCC[C@H](C)[C@H]1CCC2C3CC=C4C[C@@H](O)CCC4(C)C3CC[C@]21C</smiles>

Cholesterol<smiles>CC[C@H](/C=C/[C@H](C)[C@H]1CCC2C3CC=C4C[C@@H](O)CC[C@]4(C)C3CC[C@]21C)C(C)C</smiles>

Stigmasterol<smiles>C[C@@H]1CC[C@@]2(OC1)OC[C@H](C)C1C(CC3C4CC=C5C[C@@H](O)CC[C@]5(C)C4CC[C@@]31C)O2</smiles>

Diosgenin<smiles>CCCC1[C@@H](C(C)=O)CCC2C3CCC4=CC(=O)CC[C@]4(C)C3CC[C@@]21C</smiles>

Progesterone<smiles>C#C[C@]1(O)CCC2C3CCC4=CC(=O)CCC4C3CC[C@]21C</smiles>

Norethindrone<smiles>CC(=O)OC1(C(C)=O)CCC2C3C=C(Cl)C4=CC(=O)[C@@H]5C[C@@H]5[C@]4(C)C3CC[C@]21C</smiles>

Cyproterone acetate<smiles>C#CC1(O)CCC2C3CCC4=C(CCC(=O)C4)C3CCC21C</smiles>

Norethinodrel<smiles>C#C[C@]1(O)CCC2C3CCC4=CC(=O)CCC4C3CCC21CC</smiles>

Levonorgestrel

\section{Scheme 1.3}

norethindrone [30]. Scientists at Searle reported at just about the same time the successful synthesis of the double-bond isomer of norethindrone, named norethynodrel [31]. Both compounds revealed approximately twice the activity of progesterone in animal studies when given orally. These results triggered clinical studies [32] that ended with the market introduction of Enovid (norethynodrel) in 1959 and Ortho-Novum (norethindrone) in 1962 as oral contraceptives. With the introduction of these two oral contraceptives into the marketplace, the era of 
progesterone receptor ligands entered a new phase. More potent progestines, like levonorgestrel and gestodene, and progestines with a special favorable profile on other nuclear receptors, like cyproterone acetate and drospirenone, were discovered during the following decades of intense research efforts in this field [33]. Cyproterone acetate was the first progestin with a potent antiandrogenic effect and it is still in use for the treatment of prostate cancer [34]. Drospirenone is structurally related to the aldosterone antagonist spironolactone. It has not only progestagenic properties, but is also a very potent antimineralocorticoid and it also shows antiandrogenic activity [35]. This pharmacodynamic profile is quite close to the natural progesterone.

\subsection{4}

\section{Other Receptor Research}

As these early research efforts had resulted in modulators of the steroid receptor subgroup of the nuclear receptor family, these compounds could be used to support the purification of the receptors in the first nuclear receptor gene-cloning studies. The first human nuclear receptor that was cloned was the GR. This was achieved by using reagents made available from the purification and biochemical characterization of adrenal extracts. With purified receptor, selective antibodies were used to help isolate the corresponding cDNA [36, 37]. cDNAs with the full-length coding region of GR provided the first full-length amino acid sequence of a nuclear receptor. Around the same time three research groups independently succeeded in cloning also the estrogen receptor (ER) [38-40]. The comparison of nuclear receptor sequences from human and other species revealed conserved domains in the nuclear receptor family.

The finding that nuclear receptors could be isolated without prior knowledge of their ligand triggered research for new nuclear receptors. The number of orphan nuclear receptors rapidly exceeded the number of classical nuclear hormone receptors [41-43]. The preferred method for the identification of new nuclear receptors shifted from the laboratory to in silico methods due to the availability of large databases of randomly generated partial cDNA sequences known as expressed sequence tags (ESTs) and new bioinformatic query tools. Two new mammalian nuclear receptors were successfully identified through automated searches of EST databases. The pregnane $\mathrm{X}$ receptor (PXR) was discovered in a public mouse EST database by a high-throughput in silico screen for nuclear receptor-like sequences [44] and the photoreceptor cell-specific receptor (PNR) was identified in a human EST database [45]. Finally the number of known human nuclear receptors reached 48 after the PNR was isolated from EST databases. In 2001, the availability of the complete human genome sequence confirmed that there are 48 members in the human nuclear receptor family $[46,47]$ (Table 1.1 ).

The nuclear receptor superfamily can be generally divided into four major subfamilies based on their DNA-binding properties and dimerization preferences. However, this classification is rather broad and does not take into account of any evolutionary relationship between nuclear receptors. Therefore, a new phylogeny-based nomenclature approved by the Nuclear Receptor Nomenclature 
\begin{tabular}{l|l}
1.2 Short Historical Overview on Nuclear Receptors in Pharmacological Research and Drug Discovery & 7
\end{tabular}

Table 1.1 List of human nuclear receptors and systematic nomenclature.

\begin{tabular}{|c|c|c|c|}
\hline Name & Abbreviation & Nomenclature & Ligand \\
\hline \multirow[t]{2}{*}{ Thyroid hormone receptor } & $\mathrm{TR} \alpha$ & NR1A1 & thyroid hormone \\
\hline & $\operatorname{TR} \beta$ & NR1A2 & thyroid hormone \\
\hline \multirow[t]{3}{*}{ Retinoic acid receptor } & $\operatorname{RAR} \alpha$ & NR1B1 & retinoic acid \\
\hline & RAR $\beta$ & NR1B2 & retinoic acid \\
\hline & $\mathrm{RAR} \gamma$ & NR1B3 & retinoic acid \\
\hline \multirow{3}{*}{$\begin{array}{l}\text { Peroxisome proliferator- } \\
\text { activated receptor }\end{array}$} & $\operatorname{PPAR} \alpha$ & NR1C1 & fatty acids, \\
\hline & PPAR $\beta$ & NR1C2 & $\begin{array}{l}\text { leukotriene B4 } \\
\text { fatty acids }\end{array}$ \\
\hline & $\operatorname{PPAR} \gamma$ & NR1C3 & $\begin{array}{l}\text { fatty acids, } \\
\text { prostaglandin J2 }\end{array}$ \\
\hline \multirow[t]{2}{*}{ Reverse erbA } & Rev-erb $\alpha$ & NR1D1 & orphan \\
\hline & Rev-erb $\beta$ & NR1D1 & orphan \\
\hline \multirow{3}{*}{$\begin{array}{l}\text { Retinoic acid receptor-related } \\
\text { orphan receptor }\end{array}$} & $\mathrm{ROR} \alpha$ & NR1F1 & cholesterol \\
\hline & $\mathrm{ROR} \beta$ & NR1F2 & retinoic acid \\
\hline & $\mathrm{ROR} \gamma$ & NR1F3 & retinoic acid \\
\hline \multirow[t]{2}{*}{ Liver $\mathrm{X}$ receptor } & $\mathrm{LXR} \alpha$ & NR1H3 & oxysterols \\
\hline & LXR $\beta$ & $\mathrm{NR} 1 \mathrm{H} 2$ & oxysterols \\
\hline \multirow[t]{2}{*}{ Farnesoid X receptor } & $\mathrm{FXR} \alpha$ & NR1H4 & bile acids \\
\hline & FXR $\beta$ & NR1H5 & lanosterols \\
\hline Vitamin D receptor & VDR & NR1I1 & vitamin D \\
\hline Pregnane $\mathrm{X}$ receptor & PXR & NR1I2 & xenobiotics \\
\hline Constitutive androstane receptor & CAR & NR1I3 & xenobiotics \\
\hline \multirow[t]{2}{*}{ Human nuclear factor 4} & $\mathrm{HNF} 4 \alpha$ & NR2A1 & orphan \\
\hline & $\mathrm{HNF} 4 \gamma$ & NR2A2 & orphan \\
\hline \multirow[t]{3}{*}{ Retinoid X receptor } & $\mathrm{RXR} \alpha$ & NR2B1 & retinoic acid \\
\hline & $\mathrm{RXR} \beta$ & NR2B2 & retinoic acid \\
\hline & $\mathrm{RXR} \gamma$ & NR2B3 & retinoic acid \\
\hline \multirow[t]{2}{*}{ Testis receptor } & TR2 & NR2C1 & orphan \\
\hline & TR4 & NR2C2 & orphan \\
\hline Tailless & TLL & NR2E2 & orphan \\
\hline $\begin{array}{l}\text { Photoreceptor-specific } \\
\text { nuclear receptor }\end{array}$ & PNR & NR2E3 & orphan \\
\hline \multirow{2}{*}{$\begin{array}{l}\text { Chicken ovalbumin upstream } \\
\text { promoter-transcription factor }\end{array}$} & COUP-TFI & NR2F1 & orphan \\
\hline & COUP-TFII & NR2F2 & orphan \\
\hline ErbA2-related gene-2 & EAR2 & NR2F6 & orphan \\
\hline \multirow[t]{2}{*}{ Estrogen receptor } & $\mathrm{ER} \alpha$ & NR3A1 & estradiol \\
\hline & $\mathrm{ER} \beta$ & NR3A2 & estradiol \\
\hline \multirow[t]{3}{*}{ Estrogen receptor-related receptor } & $\mathrm{ERR} \alpha$ & NR3B1 & orphan \\
\hline & $\operatorname{ERR} \beta$ & NR3B2 & orphan \\
\hline & $\mathrm{ERR} \gamma$ & NR3B3 & orphan \\
\hline Glucocorticoid receptor & GR & NR3C1 & cortisol \\
\hline Mineralocorticoid receptor & MR & NR3C2 & aldosterone \\
\hline Progesterone receptor & PR & NR3C3 & progesterone \\
\hline
\end{tabular}

(Continued) 
Table 1.1 (Continued)

\begin{tabular}{llll}
\hline Name & Abbreviation & Nomenclature & Ligand \\
\hline Androgen receptor & AR & NR3C4 & testosterone \\
Nerve growth factor-induced factor B & NGFI-B & NR4A1 & orphan \\
Nur-related factor 1 & NURR1 & NR4A2 & orphan \\
Neuron-derived orphan receptor 1 & NOR1 & NR4A3 & orphan \\
Steroidogenic factor-1 & SF1 & NR5A1 & orphan \\
Liver receptor homologous protein 1 & LRH1 & NR5A2 & orphan \\
Germ cell nuclear factor & GCNF & NR6A1 & orphan \\
$\begin{array}{l}\text { DSS-AHC critical region on the } \\
\text { chromosome gene 1 }\end{array}$ & DAX1 & NR0B1 & orphan \\
Short heterodimeric partner & SHP & NR0B2 & orphan
\end{tabular}

Committee has been proposed for nuclear receptors in addition to the original names [48]. This nomenclature system is based upon multiple alignment procedures and phylogenetic tree reconstruction methods, which finally led to the subdivision of the nuclear receptor superfamily into seven subfamilies which are numbered from 0 to 6 . The phylogenetically closest members of each subfamily are combined into groups designated by capital letters arranged in the alphabetical order and the individual genes within each group are numbered. This nomenclature system should overcome the problem of the existence of several names and abbreviations of the same gene.

With the discovery of new nuclear receptors, novel interdependencies between first-generation drugs and their targets were detected. For example, traditional pharmacological research methods had revealed earlier that thiazolidinediones (TZDs) have a clinical benefit in diabetes; however, the molecular basis for this therapeutic effect was not known. By using expression constructs derived from the isolated nuclear receptor genes, activity screens for each receptor were developed. By using such screens it was found that TZDs are potent and selective activators of peroxisome-proliferator-activated receptor (PPAR) $\gamma$ [49]. After discovery of this connection, the search for a second-generation PPAR $\gamma$ compounds was started using an in vitro assay for PPAR $\gamma$ activation. This second-generation approach of using the receptor rather than a bioactive extract can be characterized as a 'reverse endocrinology' approach. Historically, ligands of nuclear receptors have been discovered due to their biological effects. In a modern reversal of this process, the orphan receptors can be used to identify ligands, which then can be used to study the biological role of the receptors.

In such a reverse endocrinology approach the farnesoid X receptor (FXR) could be connected to bile acid ligands. By further exploration of bile acids and other chemical probes for FXR it was discovered that FXR is linked to bile acid homeostasis, and it was postulated that FXR ligands might have beneficial effects for the treatment of cholestatic liver disease and other disorders [50].

Recently, a third-generation drug discovery effort has begun in the field of nuclear receptors research. Newer screening methods which deliver additional information 
besides potency and selectivity (e.g. selective effects on gene expression) can be used to discover leads with therapeutic advantages over drugs on the market.

\section{3}

\section{Recent Progress in Nuclear Receptor Drug Discovery}

Nuclear receptors have been studied in drug discovery research for decades. Synthetic ligands for a certain receptor usually have been identified through highthroughput screening (HTS) or structure-based drug design approaches. In the second step these lead structures have to be optimized further by medicinal chemists to adjust the properties of these compounds to appropriately modulate the activities of the receptor. Ligands that display differential activities compared to the natural ligand have been referred to as selective nuclear receptor modulators. Originally this concept was demonstrated for the ER with the selective ER modulators (SERMs), 4-OH-tamoxifen and raloxifene. These SERMs retained tissue-selective agonist activity in bone tissue and on lipid profile for raloxifene, but functioned as antagonists in reproductive tissues [51, 52]. Although both molecules were originally considered to be 'antiestrogens', 4-OH-tamoxifen demonstrated a general trend toward estradiol-like activity in uterine tissue, whereas raloxifene had no such activity. These pioneering experiments related to novel ER ligands triggered studies for the identification of novel, tissue-selective synthetic modulators for several of the therapeutically relevant nuclear receptors. Overall, the current goal of nuclear receptor drug discovery efforts in many cases is to manipulate the receptor with a ligand to retain tissue-selective benefits while minimizing unwanted side activities.

\subsection{1}

\section{SERMs}

The stilbene derivative tamoxifen was the first synthetic nuclear receptor smallmolecule modulator that demonstrated differential tissue effects. However, it has not found wide application as treatment for menopausal symptoms due to its stimulatory effects on the uterus which cause a potential risk for endometrial cancer [53]. Despite this drawback tamoxifen is still used as a treatment for ER-positive breast cancer.

Raloxifene, a second-generation SERM, was originally developed as a follow-up agent for tamoxifen in breast cancer. During development studies it was found that this modulator has significant osteoporosis protective effects without the endometrial activities of tamoxifen [54]. The molecular basis for these ER-modulating properties has been at the center of major pharmacological research activities [55]. One possible mechanism that was suggested is the differential effects of SERM bound ER to promote corepressor association versus coactivator association [56, 57]. Following a theoretical approach that small-molecule ligands can induce specific ER conformations several triphenylethylene ligands for ER were prepared and screened through an uterine Ishikawa cellular assay [58]. Compounds which decreased estrogen-mediated 
Ishikawa cell stimulation were then tested in ovariectomized rats for the ability to protect against loss of bone mineral density. It was found that GW5638 had antagonist properties on the uterus and agonist activities on bone and the cardiovascular system [59]. In further experiments it was shown that the biological properties of GW5638 derive from triggering a structural conformation of ER different from the conformations imposed by other SERMs [60]. Recently, several novel SERMs (e.g. bazedoxifene, lasofoxifene) have been identified with a combination of cellular screens, primarily uterine- and breast cell-based assays [61-63] (Scheme 1.4).<smiles>CC/C(=C(\c1ccccc1)c1ccc(OCCN(C)C)cc1)c1ccccc1</smiles>

Tamoxifen

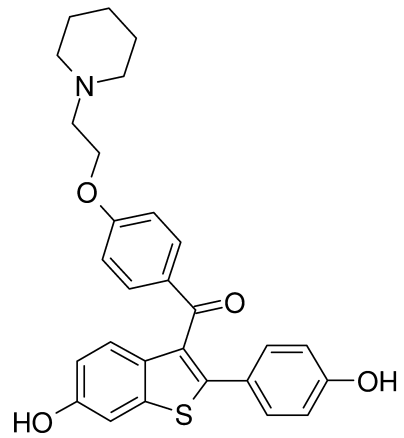

Raloxifen<smiles>CC/C(=C(\c1ccccc1)c1ccc(/C=C/C(=O)O)cc1)c1ccccc1</smiles>

GW5638<smiles>CCOC(=O)OC(C)(C)C</smiles><smiles>COC(C)(C)OCCOc1ccc([C@H]2c3ccc(O)cc3CC[C@H]2c2ccccc2)cc1</smiles>

Scheme 1.4

Two other novel approaches have recently been reported in the field of ER ligand discovery. The potential of compounds as pathway-selective ligands and antiinflammatory agents was studied by the use of NFKB-driven reporter assays [64]. A second relatively recent focus for ER-directed drug discovery is related to the fact that there are two subtypes of this receptor, ER $\alpha$ and ER $\beta$, which derive from two separate genes $[65,66]$. Stimulated by the specific tissue distribution pattern of these two related receptors, research to find ER subtype-selective modulators for the treatment 
of various diseases was triggered. Several reports have demonstrated that it is possible to identify ER $\beta$-selective ligands $[67,68]$.

\subsection{2}

\section{Selective GR Modulators}

The classic synthetic glucocorticoids dexamethasone and prednisone are in use for the treatment of various severe diseases such as rheumatoid arthritis, inflammatory myopathies, cancers and several immunological disorders. Unfortunately, long-term treatment with these drugs often triggers serious side-effects such as fat redistribution, diabetes, vascular necrosis and osteoporosis. Therefore, major drug discovery efforts are currently ongoing to find novel chemical entities that are able to differentially modulate GR to retain the beneficial effects of glucocorticoids without the unwanted side-effects of current treatments [69]. Many of the antiinflammatory effects of GR are believed to be driven by the ability of the monomeric form of the receptor to interfere with $\mathrm{NFKB}$ and AP-1 function, which ultimately results in the reduction of proinflammatory cytokines such as interleukins (IL)-1, -2, -6 and -8, and tumor necrosis factor- $\alpha$ [70]. Various chemical ligand series which display differential GR activation have been reported. Three main methods for measurement of GR activity were used to identify these ligands: (i) direct GR binding compared to other steroid receptors, (ii) a cell-based assay measuring glucocorticoid response elementmediated gene transcription (transactivation), and (iii) cell-based assays measuring the ability of GR to regulate NFKB and AP-1-driven genes (transrepression) . Several steroid-based compounds have been shown to differentially decrease transactivation with only minimal effects toward transrepression [71, 72]. A quinoline-based series of compounds described as a nonsteroidal class of GR ligands was found to have a trend toward a preferred transactivation/transrepression profile in cellular assays. Some of these ligands also demonstrated a more promising therapeutic window for selective in vivo effects [73, 74]. Another nonsteroidal GR ligand, ZK 216348, showed significant dissociation of transactivation and transrepression activities [75]. Thorough pharmacological characterization in vitro proved that ZK 216348 is a dissociative molecule. Further in vivo experiments with an ear inflammatory model for efficacy and models for skin atrophy, weight gain, adrenal weight and blood glucose levels for unwanted side-effects showed an improved therapeutic profile relative to prednisone (Scheme 1.5).

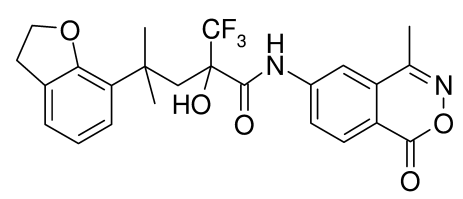

ZK 216348

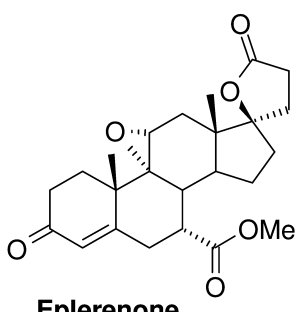

Eplerenone<smiles>COC[C@]1(OC)CCC2C3CCC4=CC(=O)CCC4=C3[C@@H](c3ccc(/C=N/O)cc3)C[C@]21C</smiles>

Asoprisnil

Scheme 1.5 


\subsection{3}

\section{Other Modulator Efforts: PR, MR, AR, PPAR, FXR and LXR (see Table 1.1)}

The theory of selective nuclear receptor modulation to achieve therapeutic value by an optimized activity profile different from the natural ligand has been also experimentally studied in several other receptors.

An example from the PR is the steroid ligand asoprisnil, which has been shown to produce antiuterotrophic effects with only minimal labor-inducing and breakthrough bleeding effects [76].

Eplerenone, a selective MR modulator, was discovered decades ago and has recently received approval as a treatment for hypertension [77]. This synthetic steroid derivative has a higher specificity for MR relative to other nuclear receptors and works as a partial antagonist of aldosterone [78].

Modulators of the AR for application in prostate cancer and possibly treating the neurological and muscular degenerative symptoms of androgen deficiency form the basis of another field of intense research efforts [79, 80]. LGD2226 is a recent example of a tissue-selective AR modulator, which seems to retain some anabolic effects on bone and muscle with reduced proliferative effects on the prostate [81].

Selective modulators for PPAR $\gamma$ (SPPARMs) have been successfully discovered by several groups. The first-generation TZD class of PPAR $\gamma$ agonists which are in use as insulin sensitizers show dose-limiting issues such as hemodilution and edema. It was found in early experiments of PPAR $\gamma$ activation by TZDs that these ligands activate through direct interaction with the C-terminal AF-2 helix [82]. Structural studies have also revealed PPAR $\gamma$ activators that bind the ligand-binding domain (LBD) using non-TZD epitopes such as the partial agonist GW0072 [83]. Ligands with specific binding and activation modes are a potential starting point for the discovery of PPAR $\gamma$ modulators with improved biological activities. Non-TZD-selective PPAR $\gamma$ modulators have been discovered which induce an altered LBD conformation compared with TZDs [84]. These compounds demonstrated qualitative differences versus traditional agonists toward gene expression in cell culture and in vivo, as well as toward in vivo physiological responses such as adipose depot size. Therefore, further research efforts to come up with novel SPPARMs may lead to compounds with improved characteristics compared to currently used therapeutics.

FXR and the LXRs are other examples of nuclear receptors for which modulators have been investigated recently $[85,86]$. It was possible to identify ligands with potential novel biological activity compared to the natural ligands (e.g. the potent synthetic FXR agonist GW4064 [87]). LXR $\alpha / \beta$ are regulated in vivo by oxysterols and this regulation is in accordance with the role of the LXRs in cholesterol homeostasis [88]. Studies with nonsubtype-selective LXR tool compounds in animal models revealed that besides atheroprotective effects, these agonists also promote lipogenesis and triglyceride accumulation in liver. The LXR agonists T0901317 and GW3965 show differential effects on cofactor recruitment in human hepatoma cell assays. Furthermore, these two ligands show different in vivo effects on hepatic lipogenesis genes. As LXR $\alpha$ is the dominant subtype in the liver, where LXR $\beta$ is expressed at very low levels, there might be a good chance that an LXR $\beta$-selective agonist may retain 
efficacy without increasing hepatic lipogenesis. $N$-Acylthiadiazolines were reported recently as a new class of LXR agonists with selectivity for LXR $\beta$ [89] (Scheme 1.6).<smiles>CCCCCCC[C@@H]1CC(CC(=O)N(Cc2ccccc2)Cc2ccccc2)C(=O)N1CCCCc1ccc(C(=O)O)cc1</smiles>

GW 0072<smiles>CC(C)(C)OCc1ccc(/C=C/Cc2ccc(C(=O)O)cc2)c(Cl)c1</smiles><smiles>O=S(=O)(c1ccccc1)N(CC(F)(F)F)c1ccc(C(O)(C(F)(F)F)C(F)(F)F)cc1</smiles>

T0901317<smiles>O=C(O)Cc1cccc(OCCCN(Cc2cccc(C(F)(F)F)c2Cl)CC(c2ccccc2)c2ccccc2)c1</smiles>

GW 3965<smiles>COc1cccc([C@H]2SC(c3ccc(Cl)cc3)=NN2C(=O)c2c(F)cc(F)cc2F)c1OC</smiles>

$N$-Acylthiadiazoline LXR $\beta$ agonist

\section{Scheme 1.6}

More experimental studies will be necessary to better understand the molecular basis of modulator effects both for the steroid receptor and nonsteroid receptor modulators.

In summary, these examples show the high degree of complexity required at several levels, such as high-affinity binding to the receptor, induction of conformational change or altered structural dynamics, selection of an appropriate cellular assay for measuring nuclear receptor modulation as well as selection of relevant in vivo models for determining any therapeutic effects. Due to structural and functional similarities within the nuclear receptors superfamily, there is a high probability that knowledge created from one receptor concerning modulation by a synthetic ligand can be applied to other members of the family [90,91]. This increased knowledge of nuclear receptor functions will be the base for novel, safer and more effective drugs. New technologies to profile ligands are especially important for rapid progress into this direction.

\section{4}

\section{Modern Methods and Technologies in Nuclear Receptor Drug Discovery}

New technologies in molecular biology, structural biology, computational methods and peptide interaction methods are important tools for discovering novel drug 
candidates for the modulation of specific nuclear receptors. These novel technologies enable rapid profiling of nuclear receptor ligands in a more physiologically relevant manner.

\subsection{1}

\section{Cofactor Interaction Screening}

Nuclear receptors do not act in an isolated way, but in complex associations with other cellular factors. Cofactor interaction screening can give valuable insights into the relationship between nuclear receptor structure and functional activity [92]. If a certain ligand changes the pattern of cofactor interaction compared to other ligands, it is likely that the different in vitro profile will translate into a special gene expression pattern or physiological outcome in vivo. Peptides representing these interactions can be prepared based on known interaction motifs or isolated through HTS of random peptide libraries. This method has been applied to characterize known SERMs and to discover ER ligands with unique properties. Affinity selection of peptides has been used to identify binding surfaces that are exposed on $E R \alpha / \beta$ when complexed with different ligands, such as with estradiol or 4-OH-tamoxifen [93]. It was discovered that the established SERMs, which are known to produce distinct biological effects, induced specific conformational changes in the receptors. Ligand screens for subtle differences between ER ligands have been performed based on nuclear receptor-peptide interactions using a high-throughput multiplexed technology, which used fluorescently encoded microspheres $[94,95]$. The repertoire of novel nuclear receptor-interacting cofactors has strongly expanded in the past few years. For the rapid identification of novel interacting cofactors, genome-wide screens for binding partners have been performed in yeast and mammalian-based two-hybrid systems. More than 200 human nuclear receptor cofactors have been identified. Especially for the discovery of new specific nuclear receptor modulators these interacting cofactors are of great importance as each new cofactor has the potential to give a better insight into a particular cellular interaction and thus lays the foundation for a molecular screen for ligands that uniquely affect this interaction.

\section{4 .2}

\section{Microarray Technology and Gene Expression Profiling}

Nuclear receptors are transcription factors and therefore monitoring ligand effects on nuclear receptor target genes is a powerful tool for drug discovery. This approach has been limited in the past due to difficulties and the related costs in measuring endogenous gene expression. It is now possible by using microarray technology to assess endogenous gene expression on a genome-wide scale and this technology has been used to define an unbiased set of nuclear receptor target genes. Microarray technology has been applied to differentiate the functions of ER $\alpha$ and ER $\beta$ in estrogen target organs such as bone, breast and uterus. Human U2OS osteosarcoma cells which express neither ER $\alpha$ nor ER $\beta$ were stably transfected with human $\mathrm{ER} \alpha / \beta$ 
to achieve overexpression of the receptors in this bone model system [96]. Two overlapping but distinct patterns of gene expression were found after treatment of the two cell lines with $17 \beta$-estradiol; $28 \%$ of the estradiol-regulated genes were ER $\alpha$ cell specific, whereas $11 \%$ were ER $\beta$ cell specific. These experiments enabled the functional dissection of the pathways regulated by two functionally similar receptors. Furthermore, unique sets of endogenous target genes have been identified for use in ligand-screening assays. The effects of various ER modulators on ER $\alpha$ and ER $\beta$ target genes have been studied in similar experiments with U2OS cells expressing either ER $\alpha$ or ER $\beta$ [97]. It was demonstrated by microarray analysis that raloxifene and tamoxifen regulated only $27 \%$ of the same genes in the ER $\alpha$ - and ER $\beta$-containing cells. These results give clear hints that estrogens and SERMs exert tissue-specific effects by regulating unique sets of target genes. Methods for high-throughput analysis of gene expression could be an entry into screening of large numbers of compounds in a cellular environment using a cost-effective technology. Advances in glass slide preparations for monitoring transcriptional changes of several thousand genes make it possible to assess a hit from a multiwell cell treatment over a genomewide range of genes in a cost-effective way. Slight differences between even very closely related chemical structures can be detected with such an analysis. Geneexpression profiling has been used to characterize breast cancer cells and to identify desired 'molecular fingerprints' within the experimental data [98]. In this way key 'biomarkers' can be identified that deliver information related to the phenotypic effect of a chemical modulator. The huge amounts of data generated by such an approach are challenging for bioinformatics methods. Therefore, advances in geneexpression profiling as a method for drug screening has to be complemented by progress in bioinformatics and data handling.

\subsection{3}

\section{Novel Computational Methods}

Nuclear receptor target genes have not only been discovered through experimental studies, but also in silico approaches have been developed which can accelerate nuclear receptor drug discovery. Comprehensive computational approaches can now be used to detect nuclear receptor target genes. A new computer algorithm (NUBIscan) gives the opportunity to predict nuclear receptor target sequences in regulatory regions of genes [99]. High-throughput genome-wide chromatin immunoprecipitation methods have been combined with computational methods to discover ER target genes and promoter sequences [100]. In silico methods for gene identification complement microarray approaches in an efficient way as they are not biased by target tissue or expression levels.

\subsection{4}

\section{Structural Biology}

Despite the described progress in many fields of nuclear receptor research which has also resulted in the determination of novel signalling pathways, for a 
surprisingly large group of orphan receptors the ligands have remained unidentified. Structural biology contributed important novel insights into nuclear receptorbinding domains and helped to adopt some orphan receptors by crystallography $[101,102]$. These studies suggest that not all of the orphan nuclear receptors use ligand binding in the classical way. Some orphan receptors lack the capacity for ligand binding, which suggests that they are regulated by alternative, ligandindependent mechanisms [103]. Nurr1 is an orphan nuclear receptor that has been studied thoroughly especially due to its essential role in developing and adult dopamine neurons. Therefore, ligands for Nurr1 could be of potential therapeutic value, but identification of Nurr1 ligands has proven difficult. Structural studies of the Nurr1 LBD can contribute to the explanation of these difficulties. Bulky and hydrophobic amino acid side-chains in the Nurr1 LBD occupy the space that form the LBD in other nuclear receptors, therefore prohibiting interaction with any ligand. The constitutive activity of Nurr1 can be explained by the position of its AF-2 helix, which is folded in an active conformation. Therefore, Nurr1 is the first example of a nuclear receptor that functions entirely independent of ligand binding.

\section{5}

\section{Summary and Future Developments}

Human nuclear receptors play an important role in many physiological processes such as metabolism, homeostasis, differentiation, growth and development, aging, and reproduction. This target family has a common evolutionary history as evidenced by their sequence relationship and their common cellular function [104]. Functions of nuclear receptors are highly complex and the pathways which are controlled by nuclear receptors are connected with each other as well as with numerous other partner proteins [105]. Despite this complexity, the nuclear receptor family has had a long history of successful drug discovery. Over the last decade drug discovery in the nuclear receptors field has started to develop capabilities for profiling compounds in a high-throughput manner in a setting much closer to the native physiological environment compared to previous studies [106]. New technologies like high-throughput methods in chemistry and structural biology, novel biochemical methods, and pathway analysis tools such as differential gene expression and proteomics will enable new discoveries which in the end will lead to drugs with improved therapeutic profiles. A better understanding of the ligand-induced activities that produce tissue-selective beneficial effects should enable the development of safer drugs with minimized unwanted side-effects. Furthermore, ligand discovery for the remaining orphan receptors might hold great promise. Target validation and better definition of therapeutic relevance for the remaining orphan nuclear receptors should be possible by using new tool compounds. In summary, despite its long history the nuclear receptor target family still bears tremendous potential, and nuclear receptor drug discovery should lead to highly effective and specific drugs for the future treatment of a broad variety of human diseases. 


\section{References}

1 Novac, N. and Heinzel, T. (2004) Nuclear receptors: overview and classification. Current Drug Targets - Inflammation and Allergy, 3, 335-346.

2 Mohan, R. and Heyman, R.A. (2003) Orphan nuclear receptor modulators. Current Topics in Medicinal Chemistry, 3, 1637-1647.

3 Bonet, M.L., Ribot, J., Felipe, E. and Palou, A. (2003) Vitamin A and the regulation of fat reserves. Cellular and Molecular Life Sciences, 60, 1311-1321.

4 Shao, W. and Brown, M. (2004) Advances in estrogen receptor biology: prospects for improvements in targeted breast cancer therapy. Breast Cancer Research, 6, 39-52.

5 Di Croce, L., Okret, S., Kersten, S., Gustafsson, J.A., Parker, M., Wahli, W. and Beato, M. (1999) Steroid and nuclear receptors. EMBO Journal, 18, 6201-6210.

6 Gronemeyer, H., Gustafsson, J.-A. and Laudet, V. (2004) Principles for modulation of the nuclear receptor superfamily. Nature Reviews Drug Discovery, 3, 950-964.

7 Shi, Y. (2007) Orphan nuclear receptors in drug discovery. Drug Discovery Today, 12, 440-445.

8 Moore, J.T., Collins, J.L. and Pearce, K.H. (2006) The nuclear receptor superfamily and drug discovery. ChemMedChem, 1, 504-523.

9 (a) Witzmann, R.F. (1981) Steroids: Keys to Life, Van Nostrand-Reinhold, New York; (b) Coghlan, M.J., Elmore, S.W., Kym, P.R. and Kort, M.E. (2003) The pursuit of differentiated ligands for the glucocorticoid receptor. Current Topics in Medicinal Chemistry, 3, 1617-1635.

10 Woodward, R.B., Sondheimer, F. and Taub, D. (1951) The total synthesis of cortisone. Journal of the American Chemical Society, 73, 4057.

11 Sarett, L.H., Arth, G.E., Lukes, R.M., Beyler, R.E., Poos, G.I., Johns, W.F. and Constantin, J.M. (1952) Stereospecific total synthesis of cortisone. Journal of the American Chemical Society, 74, 4974-4976.

12 Pines, S.H. (2004) The Merck bile acid cortisone process: the next-to-last word. Organic Process Research and Development, 8, 708-724.

13 Mühl, H. and Pfeilschifter, J. (2003) Geschichte der Glucocorticoide. Pharmazie in Unserer Zeit, 32, 284-287.

14 Meyer, U. (2004) Die Geschichte der Östrogene. Pharmazie in Unserer Zeit, 33, 352-356.

15 Quinkert, G. (2004) Hans Herloff Inhoffen in his times (1906-1992). European Journal of Organic Chemistry, 3727-3748.

16 Jordan, V.C. (2003) Tamoxifen: a most unlikely pioneering medicine. Nature Reviews Drug Discovery, 2, 205-213.

17 Madauss, K.P., Stewart, E.L. and Williams, S.P. (2007) The evolution of progesterone receptor ligands. Medicinal Research Reviews, 27, 374-400.

18 Fraenkel, L. (1903) Die Funktion des Corpus luteum. Archive fur Gynaekologia, 68, 438-535.

19 Herrman, E. and Stein, M. (1916) Über die Wirkung eines Hormones des Corpus luteum auf männliche und weibliche Keimdrüsen. Wien Klin Wochenschr, 29, 778-782.

20 Allen, W.M. and Corner, G.W. (1929) Physiology of the corpus luteum - II. Production of a special uterine reaction (progestational proliferation) by extracts of the corpus luteum. American Journal of Physiology, 88, 340-346.

21 Clauberg, C.W. (1930) Zur Physiologie und Pathologie der Sexualhormone, im Besonderen des Hormons des Corpus luteum. I. Der biologische Test für das Luteumhormon (das spezielle Hormon des Corpus luteum) am infantilen Kaninchen. Zentralblatt für Gynäkologie, 54, 2727-2770. 
22 Butenandt, A. and Westphal, O. (1934) Zur Isolierung und Charakterisierung des Corpus-luteum-Hormones. Berichte der Deutschen Chemischen Gesellschaft, 67, 1440-1442.

23 Hartman, M. and Wettstein, A. (1934) Ein krystallisiertes Hormon aus Corpus luteum. Helvetica Chimica Acta, 17, 878-882.

24 Slotta, K.H., Ruschig, H. and Fels, E. (1934) Reindarstellung der Hormone aus dem Corpus luteum. Berichte der Deutschen Chemischen Gesellschaft, 67, 1270-1273.

25 Wintersteiner, O. and Allen, W.M. (1934) Crystalline progestin. Journal of Biological Chemistry, 107, 321-336.

26 Fieser, L. and Fieser, M. (1959) Steroids, Reinhold, New York.

27 Haberlandt, L. (1924) Über hormonale Sterilisierung des weiblichen Tierkörpers. Ein Beitag zur Lehre von der inneren Sekretion des Eierstockes und der Plazenta, Urban \& Schwarzenberg, Berlin.

28 Pincus, G. (1956) Some effects of progesterone and related compounds upon reproduction and early development in mammals. Acta Endocrinologica Copenh Suppl, 28, 18-36.

29 Inhoffen, H.H., Logemann, W., Hohlweg, W. and Serini, A. (1938) Untersuchungen in der SexualhormonReihe. Chemische Berichte, 71, 1024-1032.

30 Djerassi, C., Miramontes, L., Rosenkranz, G., Sondheimer, F. and Steroids, L I V. (1954) Synthesis of 19-nor$17 \alpha$-ethynyl-testosterone and 19 -nor-17 $\alpha$ methyl-testosterone. Journal of the American Chemical Society, 76, 4092-4094.

31 Colton, F.B. (1955) US 2725389.

32 Garcia, C.R., Pincus, G. and Rock, J. (1958) Effects of three 19-nor steroids on human ovulation and menstruation. American Journal of Obstetrics and Gynecology, 75, 82-97.

33 Kulier, R., Helmerhost, F.M., Maitra, N. and Gulmezoglu, A.M. (2004) Effectiveness and acceptability of progestogens in combined oral contraceptives - a systematic review. Reprod Health, 1, 1.

34 Neumann, F. and Wiechert, R. (1984) Die Geschichte von Cyproteronacetat, Medizinisch-Pharmazeutsiche Studiengesellschaft, Mainz.

35 Krattenmacher, R. (2000) Drospirenone: pharmacology and pharmacokinetics of a unique progestogen. Contraception, 62 , 29-38.

36 Miesfeld, R., Okret, S., Wikstrom, A.C., Wrange, O., Gustafsson, J.A. and Yamamoto, K.R. (1984) Characterization of a steroid hormone receptor gene and mRNA in wild-type and mutant cells. Nature, 312, 779-781.

37 Hollenberg, S.M., Weinberger, C., Ong, E.S., Cerelli, G., Oro, A., Lebo, R., Thompson, E.B., Rosenfeld, M.G. and Evans, R.M. (1985) Primary structure and expression of a functional human glucocorticoid receptor cDNA. Nature, 318, 635-641.

38 Green, S., Walter, P., Greene, G., Krust, A., Goffin, C., Jensen, E., Scrace, G., Waterfield, M. and Chambon, P. (1986) Cloning of the human estrogen-receptor cDNA. Journal of Steroid Biochemistry, 24, 77-83.

39 Walter, P., Green, S., Greene, G., Krust, A., Bornert, J.M., Jeltsch, J.M., Staub, A., Jensen, E., Scrace, G. and Waterfield, M. (1985) Cloning of the human estrogen receptor cDNA. Proceedings of the National Academy of Sciences of the United States of America, 82, 7889-7893.

40 Greene, G.L., Gilna, P., Waterfield, M., Baker, A., Hort, Y. and Shine, J. (1986) Sequence and expression of human estrogen receptor complementary DNA. Science, 231, 1150-1154.

41 Mangelsdorf, D.J. and Evans, R.M. (1995) The RXR heterodimers and orphan receptors. Cell, 83, 841-850.

42 Blumberg, B. and Evans, R.M. (1998) Orphan nuclear receptors: new ligands 
and new possibilities. Genes Q

Development, 12, 3149-3155.

43 Giguere, V. (1999) Orphan nuclear receptors: from gene to function. Endocrine Reviews, 20, 689-725.

44 Kliewer, S.A., Moore, J.T., Wade, L., Staudinger, J.L., Watson, M.A., Jones, S.A., McKee, D.D., Oliver, B.B., Willson, T.M., Zetterstrom, R.H., Perlmann, T. and Lehmann, J.M. (1998) An orphan nuclear receptor activated by pregnanes defines a novel steroid signaling pathway. Cell, 92, 73-82.

45 Kobayashi, M., Takezawa, S., Hara, K., Yu, R.T., Umesono, Y., Agata, V., Taniwaki, M., Yasuda, K. and Umesono, K. (1999) Identification of a photoreceptor cell-specific nuclear receptor. Proceedings of the National Academy of Sciences of the United States of America, 96, 4814-4819.

46 Maglich, J.M., Sluder, A.E., Willson, T.M. and Moore, J.T. (2003) Beyond the human genome: examples of nuclear receptor analysis in model organisms and potential for drug discovery. American Journal of PharmacoGenomics, 3, 345-353.

47 Rechavi, R.-M., Carpentier, A.S., Duffraisse, M. and Laudet, V. (2001) How many nuclear hormone receptors are there in the human genome? Trends in Genetics, 17, 554-556.

48 (1999) Nuclear Receptors Nomenclature Committee. A unified nomenclature system for the nuclear receptor superfamily. Cell, 97, 161-163.

49 Lehmann, J.M., Moore, L.B., Oliver, S.-T.A., Wilkison, W.O., Willson, T.M. and Kliewer, S.A. (1995) An antidiabetic thiazolidinedione is a high affinity ligand for peroxisome proliferator-activated receptor. Journal of Biological Chemistry, 270, 12953-12956.

50 Parks, D.J., Blanchard, S.G., Bledsoe, R.K., Chandra, G., Consler, T.G., Kliewer, S.A., Stimmel, J.B., Willson, T.M., Zavacki, A.M., Moore, D.D. and Lehmann, J.M. (1999) Bile acids: natural ligands for an orphan nuclear receptor. Science, 284, 1365-1368.
51 Love, R.R., Mazess, R.B., Barden, H.S., Epstein, S., Newcomb, P.A., Jordan, V.C., Carbone, P.P. and DeMets, D.L. (1992) Effects of tamoxifen on bone mineral density in postmenopausal women with breast cancer. New England Journal of Medicine, 326, 852-856.

52 Delmas, P.D., Bjarnason, N.H., Mitlak, B.H., Ravoux, A.C., Shah, A.S., Huster, W.J., Draper, M. and Christiansen, C. (1997) Effects of raloxifene on bone mineral density, serum cholesterol concentrations, and uterine endometrium in postmenopausal women. New England Journal of Medicine, 337, 1641-1647.

53 Ismail, S.M. (1996) The effects of tamosifen on the uterus. Current Opinion in Obstetrics \& Gynecology, 8, 27-31.

54 Turner, C.H., Sato, M. and Bryant, H.U. (1994) Raloxifene preserves bone strength and bone mass in ovariectomized rats. Endocrinology, 135, 2001-2005.

55 McDonnell, D.P. (1999) The molecular pharmacology of SERMs. Trends in Endocrinology and Metabolism, 10, 301-311.

56 Shang, Y. and Brown, M. (2002) Molecular determinants for the tissue specificity of SERMs. Science, 295, 2465-2468.

57 Webb, P., Nguyen, P. and Kushner, P.J. (2003) Differential SERM effects on corepressor binding dictate ER activity in vivo. Journal of Biological Chemistry, 278, 6912-6920.

58 Willson, T.M., Henke, B.R., Momtahen, T.M., Charifson, P.S., Batchelor, K.W., Lubahn, D.B., Moore, L.B., Oliver, B.B., Sauls, H.R. and Triantafillou, J.A. (1994) 3-[4-(1,2Diphenylbut-1-enyl)phenyl]acrylic acid: a non-steroidal estrogen with functional selectivity for bone over uterus in rats. Journal of Medicinal Chemistry, 37, 1550-1552.

59 Willson, T.M., Norris, J.D., Wagner, B.L., Asplin, I., Baer, P., Brown, H.R., Jones, S.A., Henke, B., Sauls, H., Wolfe, S., Morris, D.C. and 
20| 1 Nuclear Receptors as Drug Targets: A Historical Perspective of Modern Drug Discovery

McDonnell, D.P. (1997) Dissection of the molecular mechanism of action of GW5638, a novel estrogen receptor ligand, provides insights into the role of estrogen receptor in bone. Endocrinology, 138, 3901-3911.

60 Connor, C.E., Norris, J.D., Broadwater, G., Willson, T.M., Gottardis, M.M., Dewhirst, M.W. and McDonnell, D.P. (2001) Circumventing tamoxifen resistance in breast cancers using antiestrogens that induce unique conformational changes in the estrogen receptor. Cancer Research, 61, 2917-2922.

61 Rosati, R.L. and Da Silva, J.P. (1998) Discovery and preclinical pharmacology of a novel, potent, nonsteroidal estrogen receptor agonist/antagonist, CP-336156, a diaryltetrahydronaphthalene. Journal of Medicinal Chemistry, 41, 2928-2931.

62 Bryant, H.U. (2002) Selective estrogen receptor modulators. Reviews in Endocrine Q Metabolic Disorders, 3, 231-241.

63 Meegan, M.J. and Lloyd, D.G. (2003) Advances in the science of estrogen receptor modulation. Current Medicinal Chemistry, 10, 181-210.

64 Chadwick, C.C., Chippari, S., Matelan, E., Borges-Marcucci, L., Eckert, A.M., Keith, J.C. Jr., Albert, L.M., Leathurby, Y., Harris, H.A., Bhat, R.A., Ashwell, M., Trybulski, E., Winneker, R.C., Adelman, S.J., Steffan, R.J. and Harnish, D.C. (2005) Identification of pathway-selective estrogen receptor ligands that inhibit NF- $\mathrm{B}$ transcriptional activity. Proceedings of the National Academy of Sciences of the United States of America, 102, 2543-2548.

65 Kuiper, G.G., Enmark, E., Pelto-Huikko, M., Nilsson, S. and Gustafsson, J.A. (1996) Cloning of a novel estrogen receptor expressed in rat prostate and ovary. Proceedings of the National Academy of Sciences of the United States of America, 93, 5925-5930.

66 Gustafsson, J.A. (2003) What pharmacologists can learn from recent advances in estrogen signalling. Trends in Pharmacological Sciences, 24, 479-485.

67 Henke, B.R., Consler, T.G., Go, N., Hale, R.L., Hohman, D.R., Jones, S.A., Lu, A.T., Moore, L.B., Moore, J.T., Orband-Miller, L.A., Robinett, R.G., Shearin, J., Spearing, P.K., Stewart, E.L., Turnbull, P.S., Weaver, S.L., Williams, S.P., Wisely, G.B. and Lambert, M.H. (2002) A new series of estrogen receptor modulators that display selectivity for estrogen receptor $\beta$. Journal of Medicinal Chemistry, 45, 5492-5505.

68 Manas, E.S., Unwalla, R.J., Xu, Z.B., Malamas, M.S., Miller, C.P., Harris, H.A., Hsiao, C., Akopian, T., Hum, W.T., Malakian, K., Wolfrom, S., Bapat, A., Bhat, R.A., Stahl, M.L., Somers, W.S. and Alvarez, J.C. (2004) Structure-based design of estrogen receptor- $\beta$ selective ligands. Journal of the American Chemical Society, 126, 15106-15119.

69 Miner, J.N., Hong, M.H. and Negro-Vilar, A. (2005) New and improved glucocorticoid receptor ligands. Expert Opinion on Investigational Drugs, 14, 1527-1545.

70 McKay, L.I. and Cidlowski, J.A. (1999) Molecular control of immune/ inflammatory responses: interactions between nuclear factor- $\kappa \mathrm{B}$ and steroid receptor-signaling pathways. Endocrine Reviews, 20, 435-459.

71 Walker, B.R. (2000) Deflazacort: towards selective glucocorticoid receptor modulation? Clinical Endocrinology, 52, 13-15.

72 Vayssiere, B.M., Dupont, S., Choquart, A., Petit, F., Garcia, T., Marchandeau, C., Gronemeyer, H. and Resche-Rigon, M. (1997) Synthetic glucocorticoids that dissociate transactivation and AP-1 transrepression exhibit antiinflammatory activity in vivo. Molecular Endocrinology, 11, 1245-1255.

73 Elmore, S.W., Coghlan, M.J., Anderson, D.D., Pratt, J.K., Green, B.E., Wang, A.X., Stashko, M.A., Lin, C.W., 
Tyree, C.M., Miner, J.N., Jacobson, P.B., Wilcox, D.M. and Lane, B.C. (2001) Nonsteroidal selective glucocorticoid modulators: the effect of C-5 alkyl substitution on the transcriptional activation/repression profile of 2,5dihydro-10-methoxy-2,2,4-trimethyl-1h[1]benzopyrano[3,4-f]quinolines. Journal of Medicinal Chemistry, 44, 4481-4491.

74 Elmore, S.W., Pratt, J.K., Coghlan, M.J., Mao, Y., Green, B.E., Anderson, D.D., Stashko, M.A., Lin, C.W., Falls, D., Nakane, M., Miller, L., Tyree, C.M., Miner, J.N. and Lane, B. (2004) Differentiation of in vitro transcriptional repression and activation profiles of selective glucocorticoid modulators. Bioorganic \& Medicinal Chemistry Letters, 14, 1721-1727.

75 Schaecke, H., Schottelius, A., Docke, W.D., Strehlke, P., Jaroch, S., Schmees, N., Rehwinkel, H., Hennekes, H. and Asadullah, K. (2004) Dissociation of transactivation from transrepression by a selective glucocorticoid receptor agonist leads to separation of therapeutic effects from side effects. Proceedings of the National Academy of Sciences of the United States of America, 101, 227-232.

76 DeManno, D., Elger, W., Garg, R., Lee, R., Schneider, B., Stumpp, H.-H., Schubert, G. and Chwalisz, K. (2003) Asoprisnil (J867): a selective progesterone receptor modulator for gynecological therapy. Steroids, 68, 1019-1032.

77 Barnes, B.J. and Howard, P.A. (2005) Eplerenone: a selective aldosterone receptor antagonist for patients with heart failure. Ann Pharmacother, 39, 68-76.

78 Delyani, J.A. (2000) Mineralocorticoid receptor antagonists: the evolution of utility and pharmacology. Kidney International, 57, 1408-1411.

79 Tan, R.S., Pu, S.J. and Culberson, J.W. (2004) Role of androgens in mild cognitive impairment and possible interventions during andropause. Medical Hypotheses, 62, 14-18.
80 Santos, A.F., Huang, H. and Tindall, D.J. (2004) The androgen receptor: a potential target for therapy of prostate cancer. Steroids, 69, 79-85.

81 Rosen, J. and Negro-Vilar, A. (2002) Novel, non-steroidal, selective androgen receptor modulators (SARMs) with anabolic activity in bone and muscle and improved safety profile. Journal of Musculoskeletal and Neuronal Interactions, 32, 222-224.

82 Nolte, R.T., Wisely, G.B., Westin, S., Cobb, J.E., Lambert, M.H., Kurokawa, R., Rosenfeld, M.G., Willson, T.M., Glass, C.K. and Milburn, M.V. (1998) Ligand binding and co-activator assembly of the peroxisome proliferator-activated receptor- $\gamma$. Nature, 395, 137-143.

83 Oberfield, J.L., Collins, J.L., Holmes, C.P., Goreham, D.M., Cooper, J.P., Cobb, J.E., Lenhard, J.M., Ryde, H.-E.A., Mohr, C.P., Blanchard, S.G., Parks, D.J., Moore, L.B., Lehmann, J.M., Plunket, K., Miller, A.B., Milburn, M.V., Kliewer, S.A. and Willson, T.M. (1999) A peroxisome proliferator-activated receptor $\gamma$ ligand inhibits adipocyte differentiation. Proceedings of the National Academy of Sciences of the United States of America, 96, 6102-6106.

84 Berger, J.P., Petro, A.E., Macnaul, K.L., Kelly, L.J., Zhang, B.B., Richards, K., Elbrecht, A., Johnson, B.A., Zhou, G., Doebber, T.W., Biswas, C., Parikh, M., Sharma, N., Tanen, M.R., Thompson, G.M., Ventre, J., Adams, A.D., Mosley, R., Surwit, R.S. and Moller, D.E. (2003) Distinct properties and advantages of a novel peroxisome proliferator-activated protein $\gamma$ selective modulator. Molecular Endocrinology, 17, 662-676.

85 Downes, M., Verdecia, M.A., Roecker, A.J., Hughes, R., Hogenesch, J.B., Kast-Woelbern, H.R., Bowman, M.E., Ferrer, J.L., Anisfeld, A.M., Edwards, P.A., Rosenfeld, J.M., Alvarez, J.G., Noel, J.P., Nicolaou, K.C. and Evans, R.M. (2003) 
22 1 Nuclear Receptors as Drug Targets: A Historical Perspective of Modern Drug Discovery

A chemical, genetic, and structural analysis of the nuclear bile acid receptor FXR. Molecules and cells, 11, 1079-1092.

86 Miao, B., Zondlo, S., Gibbs, S., Cromley, D., Hosagrahara, V.P., Kirchgessner, T.G., Billheimer, J. and Mukherjee, R. (2004) Raising HDL cholesterol without inducing hepatic steatosis and hypertriglyceridemia by a selective LXR modulator. Journal of Lipid Research, 45, 1410-1417.

87 Fiorucci, S., Rizzo, G., Donini, A., Distrutti, E. and Santucci, L. (2007) Targeting Farnesoid X receptor for liver and metabolic disorder. Trends in Molecular Medicine, 13, 298-309.

88 Makishima, M. (2005) Nuclear receptors as targets for drug development: regulation of cholesterol and bile acid metabolism by nuclear receptors. Journal of Pharmacological Sciences, 97, 177-183.

89 Molteni, V., Li, X., Nabakka, J., Liang, F., Wityak, J., Koder, A., Vargas, L., Romeo, R., Mitro, N., Mak, P.A., Seidel, H.M., Haslam, J., Chow, D., Tuntland, T., Spalding, T.A., Brock, A., Bradley, M., Castrillo, A., Tontonoz, P. and Saez, E. (2007) N-Acylthiadiazolines, a new class of liver $\mathrm{X}$ receptor agonists with selectivity for LXR $\beta$. Journal of Medicinal Chemistry, 50, 4255-4259.

90 Folkertsma, S., van Noort, P., Van Durme, J., Joosten, H.J., Bettler, E., Fleuren, W., Oliveira, L., Horn, F., de Vlieg, J. and Vriend, G. (2004) A family-based approach reveals the function of residues in the nuclear receptor ligand-binding domain. Journal of Molecular Biology, 341, 321-335.

91 Baxter, J.D., Funder, J.W., Apriletti, J.W. and Webb, V. (2004) Towards selectively modulating mineralocorticoid receptor function: lessons from other systems. Molecular and Cellular Endocrinology, 217, 151-165.

92 Kremoser, C., Albers, M., Burris, T., Deuschle, U. and Koegl, M. (2007) Panning for SNuRMS: using cofactor profiling fort he rational discovery of selective nuclear receptor modulators. Drug Discovery Today, 12 , 860-869.

93 Norris, J.D., Paige, L.A., Christensen, D.J., Chang, C.Y., Huacani, M.R., Fan, D., Hamilton, P.T., Fowlkes, D.M. and McDonnell, D.P. (1999) Peptide antagonists of the human estrogen receptor. Science, 285, 744-746.

94 Iannone, M.A., Simmons, C.A., Kadwell, S.H., Svoboda, D.L., Vanderwall, D.E., Deng, S.-J., Consler, T.G., Shearin, J., Gray, J.G. and Pearce, K.H. (2004) Correlation between in vitro peptide binding profiles and cellular activities for estrogen receptor-modulating compounds. Molecular Endocrinology, 18, 1064-1081.

95 Pearce, K.H., Iannone, M.A., Simmons, C.A. and Gray, J.G. (2004) Discovery of novel nuclear receptor modulating ligands: an integral role for peptide interaction profiling. Drug Discovery Today, 9, 741-751.

96 Stossi, F., Barnett, D.H., Frasor, J., Komm, B., Lyttle, C.R. and Katzenellenbogen, B.S. (2004) Transcriptional profiling of estrogenregulated gene expression via estrogen receptor $E R \alpha$ or $E R \beta$ in human osteosarcoma cells: distinct and common target genes for these receptors. Endocrinology, 145, 3473-3486.

97 Kian Tee, M., Rogatsky, I., Foster, T.-C., Cvoro, A., An, J., Christy, R.J., Yamamoto, K.R. and Leitman, D.C. (2004) Estradiol and selective estrogen receptor modulators differentially regulate target genes with estrogen receptors $\alpha$ and $\beta$. Molecular Biology of the Cell, 15, 1262-1272.

98 Young, P.E. and Bol, D.K. (2003) Highthroughput transcriptional profiling for drug discovery and lead development. Genetic Engineering News, 23, 1-3.

99 Podvinec, M., Kaufmann, M.R., Handschin, C. and Meyer, U.A., (2002) NUBIScan, an in silico approach for prediction of nuclear receptor response 
elements. Molecular Endocrinology, 16, 1269-1279.

100 Jin, V.X., Leu, Y.W., Liyanarachchi, S., Sun, H., Fan, M., Nephew, K.P., Huang, T.H. and Davuluri, R.V. (2004) Identifying estrogen receptor $\alpha$ target genes using integrated computational genomics and chromatin immunoprecipitation microarray. Nucleic Acids Research, 32 , 6627-6635.

101 Ingraham, H.A. and Redinbo, M.R. (2005) Orphan nuclear receptors adopted by crystallography. Current Opinion in Structural Biology, 15, 708-715.

102 Kallen, J., Schlaeppi, J.-M., Bitsch, F., Filipuzzi, I., Schilb, A., Riou, V., Graham, A., Strauss, A., Geiser, M. and Fournier, B. (2004) Evidence for ligand-independent transcriptional activation of the human estrogen-related receptor $\alpha(\mathrm{ERR} \alpha)$.

Journal of Biological Chemistry, 279,

49330-49337.

103 Benoit, G., Malewicz, M. and Perlmann, T. (2004) Digging deep into the pockets of orphan nuclear receptors: insights from structural studies. Trends in Cell Biology, 14, 369-376.

104 Escriva, H., Bertrand, S. and Laudet, V. (2004) The evolution of the nuclear receptor superfamily. Essays in Biochemistry, 40, 11-26.

105 Biggins, J.B. and Koh, J.T. (2007) Chemical biology of steroid and nuclear hormone receptors. Current Opinion in Chemical Biology, 11, 99-110.

106 Shi, Y. (2006) Orphan nuclear receptors, excellent targets of drug discovery. Combinatorial Chemistry and High Throughput Screening, 9, 683-689. 
